\title{
Andrzej Paliński*
}

\section{WYBRANE TEORIE UMÓW KREDYTOWYCH - PRZEGLĄD BADAŃ}

\section{Wprowadzenie}

Teoria umów kredytowych, lub inaczej relacja kredytodawca-kredytobiorca, jest zbiorem zagadnień związanych z zawarciem umowy kredytowej i jej wykonaniem, opisujących zachowania stron umowy w trakcie całego procesu kredytowego. Teoria umów kredytowych jest uszczegółowieniem ogólnej teorii umów zawieranych w warunkach niedoskonałego rynku i asymetrii informacyjnej. Teoria umów obejmuje zagadnienia kosztów transakcji (modele kosztownej weryfikacji - costly state verification) oraz teorię umów niepełnych (incomplete contracts). $Z$ kolei zagadnienia umów wynikają z ogólniejszej teorii przedstawicielstwa (teorii agencji).

Problem przedstawicielstwa, czyli występowanie konfliktów wynikających z relacji pryncypał-agent, związany jest $\mathrm{z}$ występowaniem asymetrii informacji pomiędzy przedstawicielem a mocodawcą. Drugą przyczyną powstawania problemu przedstawicielstwa, związaną pośrednio $\mathrm{z}$ asymetrią informacji, jest konieczność ponoszenia kosztów związanych z przygotowaniem, monitorowaniem i realizacją kontraktów pomiędzy stronami relacji przedstawicielstwa.

W tym kontekście nie wiadomo tak naprawdę, jak powinna wyglądać optymalna umowa kredytowa. Mogłaby ona zostać skonstruowana na przykład według zasady spłaty zadłużenia proporcjonalnej do wyników przedsięwzięcia finansowanego kredytem. Rzeczywiście, w warunkach doskonałego rynku, na którym nie byłoby asymetrii informacyjnej oraz nie występowałyby koszty transakcyjne, dług przypominałby kapitał własny, a spłata dla wierzyciela zależałaby od obserwowalnych wyników przedsięwzięcia. Podział wyniku przedsięwzięcia inwestycji odbywałby się pomiędzy strony umowy na podstawie awersji do ryzyka ${ }^{1}$.

\footnotetext{
* Akademia Górniczo-Hutnicza im. Stanisława Staszica w Krakowie, Wydział Zarządzania.

1 X. Freixas, J.-C. Rochet, Microeconomics of Banking, The MIT Press, Cambridge 1997.
} 
W praktyce gospodarczej jednakże nie spotyka się powszechnie umów uzależniających wysokość spłaty zadłużenia od stanów natury, czyli wyników przedsięwzięcia. Najczęściej zawieranym kontraktem dłużnym jest standardowa umowa kredytowa o stałej, z góry określonej kwocie spłaty², brak której prowadzi do przejęcia składników majątku dłużnika przez wierzyciela. Okazuje się, że na gruncie teorii agencji, w warunkach asymetrii informacyjnej i kosztów egzekwowania kontraktów, standardowa umowa kredytowa jest optymalną formą umowy dłużnej. Na realizację tej umowy wpływają dodatkowo: wartość zabezpieczenia, możliwość renegocjacji i długookresowość relacji kredytodawca-kredytobiorca. Celem artykułu jest przegląd badań teoretycznych z zakresu umowy kredytowej.

\section{Optymalna umowa w warunkach asymetrii informacji - modele kosztownej weryfikacji}

W sytuacji asymetrii informacyjnej, gdy stan natury po zawarciu kontraktu jest znany tylko jednemu $\mathrm{z}$ agentów, nie ma bezpośredniego sposobu uwzględnienia w kontrakcie warunków płatności w uzależnieniu od nieobserwowalnych dla wszystkich stron umowy stanów natury. Zgodnie z intuicją i praktyką gospodarczą przyjmuje się założenie, że możliwe jest poznanie stanu natury dzięki zastosowaniu wymagającego poniesienia kosztu mechanizmu weryfikacji wyników przedsięwzięcia (audytu). Możliwe jest zatem pośrednie powiązanie płatności z wynikami przedsięwzięcia poprzez proces weryfikacji. Jednym z pierwszych modeli, w którym dokonano próby kompleksowego wyjaśnienia wpływu kosztów weryfikacji na kształt optymalnej umowy był model Townsenda ${ }^{3}$. Model ten wykazał optymalność standardowej umowy kredytowej dla kontraktu deterministycznego, to znaczy takiego, w którym audyt jest podejmowany na pewno, ale tylko w określonych w umowie warunkach. W pozostałych warunkach audyt nie jest podejmowany w ogóle.

Rozwinięciem ogólnego modelu Townsenda w odniesieniu do instytucji finansowych jest model Gale’a i Hellwiga ${ }^{4}$, którego główne wyniki zostały potwierdzone

\footnotetext{
2 Zmienność rynkowej stopy procentowej nie jest zależna od wyników ekonomicznych kredytobiorcy, stąd „stałość” oznacza niezależność od wyników przedsięwzięcia.

3 R. Townsend, Optimal contracts and competitive markets with costly state verification, "Journal of Economic Theory" 1979, Vol. 21, s. 265-293.

4 D. Gale, M. Hellwig, Incentive-compatible Debt Contracts, The One-Period Problem, "The Review of Economics Studies" 1985, Vol. 52, s. 647-663.
} 
przez Williamsona ${ }^{5}$. Z modelu Gale’a-Hellwiga wynika, że standardowa umowa kredytowa, w której kredytobiorca angażuje w przedsięwzięcie inwestycyjne cały swój majątek, jest optymalną umową dłużną. W warunkach neutralności względem ryzyka agentów problem podziału ryzyka nie odgrywa roli, a zagadnienie sprowadza się do minimalizacji wartości oczekiwanej kosztów weryfikacji, czyli minimalizacji zbioru upadłości.

Dążenie obydwu stron umowy do minimalizacji kosztów utraconych i zwiększenia tym samym dochodu do podziału pomiędzy nich prowadzi do umowy kredytowej o stałej kwocie spłaty. Dopiero brak spłaty wywołuje reakcję kredytodawcy związaną z weryfikacją rzeczywistych wyników przedsięwzięcia. Dążenie kredytobiorcy do uniknięcia kosztów weryfikacji i groźba upadłości skłaniają go do spłaty określonej w umowie kwoty. Tym samym, to koszty weryfikacji wyników przedsięwzięcia są przyczyną powszechności standardowych umów kredytowych jako formy umów dłużnych.

Model Gale’a-Hellwiga zakłada stosowanie jedynie strategii czystych, w których kredytodawca może albo nie podejmować decyzji o przeprowadzeniu audytu, albo ją podjąć w określonych warunkach, bez stosowania jakiejkolwiek losowości. Przy takim założeniu uzyskuje się kontrakt deterministyczny o charakterze standardowej umowy kredytowej. Inne modele wykazały jednakże możliwość istnienia równowagi w strategiach mieszanych ${ }^{6}$. Taka równowaga wyznacza kontrakt stochastyczny, w którym wierzyciel może losowo podejmować decyzję o przeprowadzeniu audytu. Kontrakt stochastyczny dominuje dług w sensie Pareto, jednakże nie jest on spotykany w umowach kredytowych, a jedynie w obszarze podatków i ubezpieczeń. Przyczyną takiej sytuacji jest brak możliwości renegocjacji umów podatkowych i ubezpieczeniowych, a także często ich obligatoryjność, co rodzi pokusę losowego pozorowania niskiego zwrotu przez dłużnika, i skutkuje losowym audytem wyników przedsięwzięcia przez wierzyciela.

W tym kontekście zainteresowanie budzi możliwość zastosowania strategii mieszanej w jednym modelu, zapewniającym obydwa typy kontraktów. Dodatkowo, słabością typowych modeli kosztownej weryfikacji, jest założenie, że egzekwowanie warunków umowy jest pełne i pozbawione kosztów. Rozwiązanie obydwu wątpliwości przyniósł model Krasa i Villamil7. Model ten stanowi uogólnienie modelu kosztownej weryfikacji przez wprowadzenie możliwości swobodnego niedotrzymania umowy

5 S. Williamson, Costly Monitoring, Loan Contracts, and Equilibrium Credit Rationing, "Quarterly Journal of Economics" 1987, Vol. 102, No. 1, s. 135-146.

6 R. Townsend, op.cit.; K. Border, J. Sobel, Samurai Accountant: A Theory of Auditing and Plunder, "Review of Economics Studies" 1987, Vol. 54, No. 4, s. 525-540; D. Mookherjee, I. Png, Optimal Auditing, Insurance and Redistribution, "Quarterly Journal of Economics" 1989, Vol. 104, No. 2, s. 399-415.

7 S. Krasa, A. Villamil, Optimal Contracts when Enforcement is a Decision Variable, "Econometrica" 2000, Vol. 68, No. 1, s. 119-134. 
przez kredytobiorcę oraz dobrowolnej decyzji kredytodawcy dotyczącej wykorzystania przymusu dla wyegzekwowania umowy. System przymusu, którym może być sąd, jest jednak niedoskonały i kosztowny. Sąd może nie być zdolny do przejęcia wszystkich aktywów dłużnika, gdyż część z nich może zostać ukryta. Poza tym, postępowanie sądowe wymaga poniesienia opłat i kosztów przez obydwie strony postępowania.

$\mathrm{Z}$ modelu Krasa i Villamil wynika, że standardowa umowa kredytowa jest nie tylko kontraktem optymalnym, ale także spójnym w czasie. Spójność w czasie oznacza, iż strony umowy nie dążą do jej zmiany po zaobserwowaniu wyników przedsięwzięcia, mimo że umowa jest podpisywana w chwili, w której wynik przedsięwzięcia nie jest jeszcze znany. Okazuje się, że standardowa umowa kredytowa jest efektywna nie tylko ex ante, ale także ex post i strony kontraktu nie będą skłonne dążyć do jej renegocjacji po zaobserwowaniu wyników przedsięwzięcia.

W modelach kosztownej weryfikacji zakłada się niejawnie, że przedsiębiorca i kredytodawca posiadają jednakowe oceny stóp zwrotu z przedsięwzięcia inwestycyjnego. Nie zawsze musi to być prawdziwe - może się okazać na przykład, że przedsiębiorca ma bardziej optymistyczne zapatrywania na wyniki planowanego przedsięwzięcia niż kredytodawca. Biorąc to pod uwagę, Carlier i Renou ${ }^{8}$ przyjęli założenie, że kredytobiorca i kredytodawca mają odmienne oceny rozkładu prawdopodobieństwa stóp zwrotu z przedsięwzięcia.

W sytuacji istnienia zróżnicowanych ocen kredytodawcy i kredytobiorcy dotyczących zwrotu z przedsięwzięcia standardowa umowa kredytowa nie zawsze jest optymalnym kontraktem dłużnym. Standardowa umowa kredytowa jest optymalna przy zróżnicowanych ocenach kredytobiorcy i kredytodawcy związanych ze zwrotem z przedsięwzięcia tylko wtedy, jeżeli ocena przez przedsiębiorcę prawdopodobieństwa zwrotu z projektu ponad kwotę spłaty kredytu przewyższa pewną wartość graniczną wyliczoną w modelu.

W rozważanych modelach brakuje założenia dotyczącego zabezpieczenia spłaty kredytu majątkiem przedsiębiorcy posiadanym przed podpisaniem kontraktu. Założenie to uwzględnia model Lackera' ${ }^{9}$. Standardowa umowa kredytowa w takiej sytuacji pozostaje również optymalną umową dłużną, pod warunkiem, iż kredytobiorca wyżej wycenia wartość zabezpieczenia niż inwestor, co zwykle występuje w praktyce gospodarczej.

Długotrwałe funkcjonowanie firmy lub duże wielookresowe przedsięwzięcia inwestycyjne wymagają dłuższej współpracy z kredytodawcami. To zagadnienie

\footnotetext{
8 G. Carlier, L. Renou, A Costly State Verification Model with Diversity of Options, "Economic Theory" 2005, Vol. 25, s. 497-504.

9 J. Lacker, Collateralized Debt as the Optimal Contract, "Review of Economic Design" 2001, Vol. 4, s. $842-859$.
} 
podejmuje D. Webb ${ }^{10}$, wykazując, że w wypadku dwuokresowego kontraktu w pierwszym okresie umowa kredytowa wiąże wysokość spłaty ze stanem natury (umowa przypominająca kapitał własny), a dopiero $\mathrm{w}$ drugim okresie jest to standardowa umowa kredytowa. C. Snyder ${ }^{11}$ wskazuje jednak kontrprzykład, który podważa ten wynik i sugeruje istnienie ogólniejszej klasy umów kredytowych.

C. Choe ${ }^{12}$ twierdzi, że nie tylko optymalność standardowej umowy kredytowej jest przyczyną jej powszechności, ale także nieprzewidywalność i zbytnie skomplikowanie rzeczywistości. Z kolei H. Hvide i T. Leite ${ }^{13}$ udowodnili, że chociaż standardowa umowa kredytowa jest optymalną formą umowy, to niewypłacalność nie jest równoznaczna z upadłością ze względu na pobłażliwość wierzycieli, co może prowadzić do strategicznej niewypłacalności.

\section{Czynniki wpływające na warunki umowy kredytowej}

Głównymi cechami umowy kredytowej oprócz określonej stałej kwoty spłaty są: zabezpieczenie spłaty, możliwość renegocjacji oraz długotrwałość więzi kredytowej. Zabezpieczenie spłaty może wpływać na autoselekcję kredytobiorców ze względu na poziom ryzyka w chwili zawierania umowy kredytowej - mniej ryzykowni kredytobiorcy wybierają umowy o niższych stopach procentowych, ale z zabezpieczeniem, w odróżnieniu od bardziej ryzykownych, którzy preferują wyższą stopę procentową w zamian za brak konieczności przedstawienia zabezpieczenia ${ }^{14}$.

Wysokie koszty banku związane z weryfikacją wyników przedsięwzięć kredytobiorcy (monitoringiem) mogą skłaniać dłużnika do przejmowania części lub całości zwrotu z przedsięwzięcia dla własnych korzyści zamiast spłaty kredytu w zależności od relacji zwrotu z przedsięwzięcia do wartości zabezpieczenia ${ }^{15}$. Takie podejście

10 D. Webb, Two-Period Financial Contracts with Private Information and Costly State Verification, "Quarterly Journal of Economics” 1992, Vol. 107, No. 3, s. 1113-1123. 2001

1 C. Snyder, Optimal Long Term Contracts in a Costly State Verification Model, MIT Press, Cambridge

12 C. Choe, A Mechanism Design Approach to an Optimal Contract Under Ex Ante and Ex Post Private Information, "Review of Economic Design" 1998, Vol. 3, s. 237-255.

13 H. Hvide, T. Leite, Optimal debt contracts under costly enforcement, "Economic Theory" 2010, Vol. 44, s. 149-165.

${ }^{14} \mathrm{H}$. Bester, Screening vs. rationing in credit markets with imperfect information, „The American Economic Review" 1985, Vol. 75, No. 4, s. 850-855.

15 O. Hart, J. Moore, Default and renegotiation: a dynamic model of debt, "The Quarterly Journal of Economics" 1998, Vol. 113, No. 1, s. 1-41; R. Barro, The Loan Market, Collateral, and Rates of Interest, "Journal of Money, Credit and Banking" 1976, Vol. 8, No. 4, s. 439-456. 
wiąże rolę zabezpieczenia spłaty z teorią umów niepełnych, w której możliwość renegocjacji pierwotnej umowy odgrywa kluczowe znaczenie.

G. Gorton i J. Kahn ${ }^{16}$ udowodnili, że w procesie renegocjacji kwota spłaty kredytu nie jest liniową i ciągłą funkcją wartości i ryzyka zabezpieczenia. Bank w pewnych warunkach może obniżać kwoty spłaty dla unikania pokusy nadużycia i zwiększania ryzyka własnych aktywów przez kredytobiorcę. Z drugiej strony, A. Boot i A. Thakor ${ }^{17}$ wykazali, że przy długotrwałej współpracy bank - kredytobiorca sukces już jednego przedsięwzięcia i spłata kredytu zapewnia obniżenie oprocentowania kolejnych kredytów.

Zabezpieczenie spłaty kredytu wiąże się z pojęciem wartość likwidacyjnej, które jest kluczowym elementem w teorii umów niepełnych i kosztów transakcyjnych. Koncepcja wartości likwidacyjnej jest pojęciem ogólnym i odnosi się do kwoty, jaką może uzyskać kredytodawca w wyniku przejęcia aktywów kredytobiorcy i sprzedania ich na rynku. Zgodnie z badaniami teoretycznymi ${ }^{18}$ wartość likwidacyjna wyznacza nie tylko wysokość kwot odzyskiwanych przez bank przy braku spłaty kredytu, ale również wpływa na rezultaty renegocjacji zadłużenia. Wynika to $\mathrm{z}$ faktu, że groźba likwidacji aktywów motywuje kredytobiorcę do unikania niewypłacalności, przez co wartość likwidacyjna determinuje ex post kwoty spłaty zadłużenia. Gdy wartość likwidacyjna jest niska, to rośnie siła przetargowa kredytobiorcy i obniżają się kwoty spłacanego zadłużenia.

\section{Umowa kredytowa jako narzędzie selekcji heterogenicznych kredytobiorców}

Wiele dyskusji i badań w obszarze umów kredytowych wzbudziło pytanie, czy kredytobiorcy, zawierając umowę kredytową w warunkach asymetrii informacyjnej, podlegają zasadzie selekcji negatywnej, czy też sami zgodnie z prawdą dostosowują umowę kredytową do swojego rzeczywistego profilu ryzyka i zwrotu z przedsięwzięć

${ }^{16}$ G. Gorton, J. Kahn, The design of bank loan contracts, "Review of Financial Studies" 2000, No. 13, s. $331-64$.

17 A. Boot, A. Thakor, Moral hazard and an secured lending in infinitely repeated market game, "International Economic Review" 1994, Vol. 35, No. 4, s. 899-920.

18 P. Aghion, P. Bolton, An Incomplete Contracts Approach to Financial Contracting, "Review of Economic Studies" 1992, Vol. 59 No. 3, s. 473-494; O. Hart, J. Moore, A Theory of Debt Based on the Inalienability of Human Capital, "The Quarterly Journal of Economics" 1994, Vol. 109, No. 4, s. 841-879; P. Bolton, D. Scharfstein, Optimal Debt Structure and the Number of Creditors, "The Journal of Political Economy" 1996, Vol. 104, No. 1, s. 1-25. 
inwestycyjnych? ${ }^{19}$. Szczególnie znaczącym okazał się w tej kwestii model H. Bestera, który doczekał się wielu badań teoretycznych i empirycznych. Część z nich potwierdzała wyniki modelu, podczas gdy inna część im zaprzeczała.

Celem modelu Bestera było znalezienie warunków, dla których w sytuacji asymetrii informacyjnej na rynku kredytowym istnieje równowaga przy braku racjonowania kredytów dla wszystkich zgłaszających popyt na środki pieniężne pochodzące od kredytodawców przy danych stopach procentowych i zabezpieczeniach spłaty. Warunkiem braku racjonowania kredytów jest zaproponowanie zestawu umów kredytowych różniących się wysokością stopy procentowej i wartością zabezpieczenia spłaty kredytu, tak aby potencjalni kredytobiorcy sami dokonywali wyboru optymalnego $\mathrm{z}$ ich punktu widzenia kontraktu dla ich profilu ryzyka.

Bester udowodnił, że w warunkach asymetrii informacyjnej zabezpieczenie spłaty kredytu stanowi narzędzie selekcji kredytobiorców różniących się poziomem ryzyka. Przedsiębiorcy o wyższym ryzyku wybierają umowę kredytową o wyższej stopie procentowej bez zabezpieczenia spłaty, podczas gdy mniej ryzykowni - umowę o niższej stopie procentowej z zabezpieczeniem spłaty kredytu.

Wyniki badań empirycznych, służących potwierdzeniu lub zakwestionowaniu modelu teoretycznego wskazującego na rolę zabezpieczenia spłaty jako narzędzia autoselekcji kredytobiorców, są niejednoznaczne. Okazuje się, że zabezpieczenie spłaty kredytu odgrywa mniejszą rolę w wypadku kredytobiorców już posiadających historię kredytową, natomiast u nowych kredytobiorców, nieznanych bankom, zabezpieczenie pełni rolę sygnalizacyjną ${ }^{20}$. Ponadto, zabezpieczenie spłaty kredytu działa jako narzędzie autoselekcji jedynie w wypadku kredytobiorców niebędących w dłuższych relacjach $\mathrm{z}$ bankiem ${ }^{21}$. Rola tak zwanego relationship lending jest szczególnie korzystna dla mniejszych banków ${ }^{22}$. Jednakże rozwój metod creditscoringowych generalnie obniżył wymagania banków dotyczące przedstawienia zabezpieczeń spłaty² ${ }^{23}$.

19 H. Bester, op.cit.; G. Clemenz, Credit Markets with Asymmetric Information, "Lecture Notes in Economics and Mathematical Systems", Springer, Berlin-Heidelberg 1986; D. Besanko, A. Thakor, Collateral and rationing: sorting equilibria in monopolistic and competitive credit markets, "International Economic Review" 1987, Vol. 28, No. 3, s. 671-689.

${ }_{20}$ G. Jimenez, V. Salas, J. Saurina, Determinants of collateral, “Journal of Financial Economics” 2006, Vol. 81, s. 255-281.

21 I. Brick, I. Palia, Evidence of jointness in the terms of relationship lending, "Journal of Financial Intermediation" 2007, Vol. 16, s. 452-476.

22 A. Berger, L. Black, Bank Size, Lending Technologies, and Small Business Finance, "Journal of Banking and Finance" 2011, Vol. 35, s. 724-735.

23 A. Berger, M. Espinosa-Vega, S. Frame, N. Miller, Why Do Borrowers Pledge Collateral? New Empirical Evidence on the Role of Asymmetric Information, "Journal of Financial Intermediation" 2011, Vol. 20, s. $55-70$. 
J. Niinimaki ${ }^{24}$, nawiązując do modelu Bestera, uwzględnił dodatkowo korelację zwrotu z przedsięwzięcia inwestycyjnego z cyklem koniunkturalnym, a także istnienie korelacji wartości zabezpieczenia spłaty z cyklem. Okazuje się, że stopa substytucji oprocentowania kredytu względem wartości zabezpieczenia spłaty jest taka sama jak w modelu Bestera jedynie wtedy, gdy nie ma równoczesnego powiązania sukcesu projektu i wartości zabezpieczenia z cyklem gospodarczym.

\section{Rola renegocjacji w umowach kredytowych}

Istotną cechą umowy kredytowej jest często spotykana w praktyce bankowej możliwość renegocjacji warunków spłaty. Niewywiązywanie się z zapisów umowy jest konsekwencją nieprzewidywalności stanów natury i trudności $z$ ich weryfikacją po podpisaniu umowy. Te cechy umów stały się fundamentem teorii umów niepełnych. Możliwość renegocjacji kredytu bankowego stanowi formę ubezpieczenia przed nieprzewidywanymi zdarzeniami dla firm o średnim ryzyku ${ }^{25}$.

Gdy istnieje możliwość renegocjacji, relacja kredytodawca - kredytobiorca ulega istotnej zmianie. Bester udowodnit ${ }^{26}$, że spłata kredytu uzyskiwana jest w warunkach strategii mieszanych, w których kredytobiorca, mimo wystarczającego zwrotu $\mathrm{z}$ przedsięwzięcia, $\mathrm{z}$ dodatnim prawdopodobieństwem próbuje wymusić na banku umorzenie części zadłużenia. Bank natomiast $\mathrm{z}$ dodatnim prawdopodobieństwem nie zgadza się na restrukturyzację i przejmuje zabezpieczenia spłaty.

Model Bestera wskazuje na to, że im wyższe ryzyko, tym częstsze zastosowanie zabezpieczenia spłaty. Wynik ten pozostaje $\mathrm{w}$ pozornej sprzeczności $\mathrm{z}$ sygnalizacyjną rolą zabezpieczenia, w której to mniej ryzykowni kredytobiorcy przedstawiają wyższe zabezpieczenie. Nie ma tutaj jednak sprzeczności - ryzyko projektu jest od samego początku znane, a jedynie realizacja projektu jest poznawana bez kosztów tylko przez przedsiębiorcę. Zatem nie mamy tu do czynienia z sytuacją sensu stricto asymetrii informacji, ale z zagadnieniem niepewności, powstającej już po zawarciu umowy i prowadzącej do pokusy nadużycia.

${ }^{24}$ J. Niinimaki, Nominal and true cost of loan collateral, "Journal of Banking and Finance" 2011, Vol. 35, s. $2782-2790$.

${ }^{25}$ A. Thakor, P. Wilson, Capital Requirements, Loan Renegotiation and The Borrower's Choice of Financing Source, "Journal of Banking and Finance" 1995, Vol. 19, s. 693-711.

${ }^{26} \mathrm{H}$. Bester, The Role of Collateral in a Model of Debt Renegotiation, "Journal of Money, Credit and Banking" 1994, Vol. 26, No. 1, s. 72-86. 
Jak się okazuje na podstawie badań teoretycznych i empirycznych, rola zabezpieczenia jako narzędzia sygnalizacji lub klasyfikacji kredytobiorców, jest znikoma. Głównym zadaniem zabezpieczenia spłaty jest właśnie ujawnianie informacji o kredytobiorcy po zawarciu umowy kredytowej oraz motywowanie kredytobiorcy do działania zgodnego z intencjami kredytodawcy ${ }^{27}$. Badania pokazują wręcz, że kredytobiorca spłaca kwotę nie większą niż wartość likwidacyjna jego aktywów z punktu widzenia banku, stąd wartość likwidacyjna ex ante powinna stanowić główny punkt odniesienia dla umowy kredytowej na etapie jej zawierania ${ }^{28}$.

\section{Wielookresowa relacja bank - kredytobiorca}

Groźba utraty zabezpieczenia spłaty kredytu może nie być jedynym powodem wywiązywania się kredytobiorcy z umowy kredytowej. Drugim powodem może być także chęć kontynuowania działalności gospodarczej, której odpowiednio wysoka rentowność i przyszłe dochody stanowią bodziec do spłaty zadłużenia wobec wierzyciela.

Zagadnienie wpływu rentowności przedsięwzięć realizowanych przez dłużnika w ciągu dwóch okresów na spłatę długu analizowane było przez P. Boltona i D. Scharfsteina $^{29}$. Z rozważanego przez autorów modelu wynika, że kredytobiorca, jeżeli tylko zwrot z przedsięwzięcia na to pozwala, dokonuje spłaty długu w pierwszym okresie na zasadach przypominających standardową umowę kredytową. Może dzięki temu prowadzić działalność gospodarczą w następnym okresie, uzyskując dalsze finansowanie. W kolejnym okresie kredytobiorca spłaca jedynie wartość odpowiadającą niskiemu zwrotowi z przedsięwzięcia.

Obszerniejsza wersja tego problemu została poddana analizie w pracy O. Hart i J. Moor ${ }^{30}$, której celem było znalezienie ogólniejszej klasy umów dłużnych, służących finansowaniu przedsięwzięć wielookresowych. Najważniejszym wnioskiem wynikającym $z$ tej pracy było wykazanie, że w warunkach umów niepełnych kontrola nad aktywami przedsięwzięcia gospodarczego przechodzi w ręce wierzyciela tylko w sytuacji braku spłaty zadłużenia. Wniosek ten jest w częściowej sprzeczności

27 G. Coco, On the use of collateral, "Journal of Economic Surveys" 2000, Vol. 14, No. 2, s. 191-214.

28 A. Paliński, Analiza ekonomicznych warunków umowy kredytowej w ujęciu teorii gier, Wydawnictwo Uniwersytetu Ekonomicznego, Katowice 2013.

29 P. Bolton, D. Scharfstein, Optimal Debt Structure and the Number of Creditors, "The Journal of Political Economy" 1996, Vol. 104, No. 1, s. 1-25.

30 O. Hart, J. Moore, Default and renegotiation: a dynamic model of debt, "The Quarterly Journal of Economics" 1998, Vol. 113, No. 1, s. 1-41. 
Z wynikami P. Aghiona i P. Boltona ${ }^{31}$, którzy stwierdzili, że kontrola nad aktywami przedsięwzięcia jest zależna od stanów natury, ale niekoniecznie są to stany oznaczające niewypłacalność.

Hart i Moor wykazali ponadto, że jeżeli posiadane przez przedsiębiorcę aktywa przynoszą w ciągu całego okresu wykorzystania jednakową rentowność, to przedsiębiorca inwestuje w przedsięwzięcie cały swój majątek i zaciąga możliwie jak najniższy kredyt na sfinansowanie brakujących środków po to, żeby po spłacie kredytu kontynuować prowadzenie działalności gospodarczej, zapewniając sobie maksymalizację wartości oczekiwanej dochodu.

\section{Podsumowanie}

Problem optymalności umowy kredytowej stanowi ważny przedmiot badań finansowych od lat 70. ubiegłego wieku. Obszerna literatura teoretyczna z zakresu umów finansowych zawiera modele oparte na wielu założeniach, dotyczących m.in.: kosztów weryfikacji wyników, selekcji negatywnej, pokusy nadużycia, podziału praw i podziału ryzyka.

W niniejszym przeglądzie badań teoretycznych skupiono się na czynnikach ograniczających kształt optymalnej umowy kredytowej, którymi są asymetria informacji i wysokie koszty weryfikacji wyników przedsięwzięć gospodarczych. Zwrócono także uwagę na elementy wpływające na realizację umowy kredytowej, takie jak: zabezpieczenie spłaty, możliwość renegocjacji i długookresowość relacji kredytodawca - kredytobiorca. Ważną kategorią ekonomiczną łączącą wymienione trzy elementy jest wartość likwidacyjna aktywów kredytobiorcy. Pojęcie wartości likwidacyjnej wiąże się z teorią umów niepełnych, w której przyjmuje się, że to potencjalna wartość likwidacyjna w największym stopniu wpływa na zachowanie dłużnika w trakcie spłaty kredytu. Ten punkt widzenia wydaje się szczególnie ważny w kontekście przyczyn kryzysu gospodarczego z 2007 r.

${ }^{31}$ P. Aghion, P. Bolton, op.cit. 


\section{Bibliografia}

Aghion P., Bolton P., An Incomplete Contracts Approach to Financial Contracting, "Review of Economic Studies" 1992, Vol. 59, No. 3.

Barro R., The Loan Market, Collateral, and Rates of Interest, "Journal of Money, Credit and Banking” 1976, Vol. 8, No. 4.

Berger A., Black L., Bank Size, Lending Technologies, and Small Business Finance, "Journal of Banking and Finance" 2011, Vol. 35.

Berger A., Espinosa-Vega M., Frame S., Miller N., Why Do Borrowers Pledge Collateral? New Empirical Evidence on the Role of Asymmetric Information, "Journal of Financial Intermediation" 2011, Vol. 20.

Besanko D., Thakor A., Collateral and rationing: sorting equilibria in monopolistic and competitive credit markets, "International Economic Review" 1987, Vol. 28, No. 3.

Bester H., Screening vs. rationing in credit markets with imperfect information, „The American Economic Review” 1985, Vol. 75, No. 4.

Bester H., The Role of Collateral in a Model of Debt Renegotiation, "Journal of Money, Credit and Banking" 1994, Vol. 26, No. 1.

Bolton P., Scharfstein D., Optimal Debt Structure and the Number of Creditors, “The Journal of Political Economy" 1996, Vol. 104, No. 1.

Boot A., Thakor A., Udell G., Secured Lending and Default Risk: Equilibrium Analysis, Policy Implications and Empirical Results, "The Economic Journal” 1991, Vol. 101, No. 406.

Boot A., Thakor A., Moral hazard and an secured lending in infinitely repeated market game, "International Economic Review" 1994, Vol. 35, No. 4.

Border K., Sobel J., Samurai Accountant: A Theory of Auditing and Plunder, "Review of Economics Studies” 1987, Vol. 54, No. 4.

Brick I., Palia I., Evidence of jointness in the terms of relationship lending, "Journal of Financial Intermediation" 2007, Vol. 16.

Carlier, G., Renou, L., A Costly State Verification Model with Diversity of Options, "Economic Theory" 2005, Vol. 25.

Choe C., A Mechanism Design Approach to an Optimal Contract Under Ex Ante and Ex Post Private Information, "Review of Economic Design" 1998, Vol. 3.

Coco G., On the use of collateral, “Journal of Economic Surveys” 2000, Vol. 14, No. 2.

Clemenz G., Credit Markets with Asymmetric Information, "Lecture Notes in Economics and Mathematical Systems", Springer, Berlin-Heidelberg 1986.

Freixas X., Rochet J.-C., Microeconomics of Banking, The MIT Press, Cambridge 1997.

Gale D., Hellwig M., Incentive-compatible Debt Contracts, The One-Period Problem, “The Review of Economics Studies" 1985, Vol. 52. 
Gorton G., Kahn J., The design of bank loan contracts, "Review of Financial Studies" 2000, No. 13.

Hart O., Moore J., A Theory of Debt Based on the Inalienability of Human Capital, "The Quarterly Journal of Economics" 1994, Vol. 109, No. 4.

Hart O., Moore J., Default and renegotiation: a dynamic model of debt, "The Quarterly Journal of Economics" 1998, Vol. 113, No. 1.

Hvide H., Leite T., Optimal debt contracts under costly enforcement, "Economic Theory" 2010, Vol. 44.

Jimenez G., Salas V., Saurina J., Determinants of collateral, "Journal of Financial Economics" 2006, Vol. 81.

Krasa S., Villamil A., Optimal Contracts when Enforcement is a Decision Variable, "Econometrica" 2000, Vol. 68, No. 1.

Lacker J., Collateralized Debt as the Optimal Contract, "Review of Economic Design" 2001, Vol. 4.

Mookherjee D., Png I., Optimal Auditing, Insurance and Redistribution, "Quarterly Journal of Economics" 1989, Vol. 104, No. 2.

Niinimaki J., Nominal and true cost of loan collateral, "Journal of Banking and Finance" 2011, Vol. 35.

Paliński A., Analiza ekonomicznych warunków umowy kredytowej w ujęciu teorii gier, Wydawnictwo Uniwersytetu Ekonomicznego, Katowice 2013.

Snyder C., Optimal Long Term Contracts in a Costly State Verification Model, MIT Press, Cambridge 2001.

Thakor A., Wilson P., Capital Requirements, Loan Renegotiation and The Borrower's Choice of Financing Source, "Journal of Banking and Finance" 1995, Vol. 19.

Townsend R., Optimal contracts and competitive markets with costly state verification, "Journal of Economic Theory" 1979, Vol. 21.

Webb D., Two-Period Financial Contracts with Private Information and Costly State Verification, "Quarterly Journal of Economics" 1992, Vol. 107, No. 3.

Williamson S., Costly Monitoring, Loan Contracts, and Equilibrium Credit Rationing, "Quarterly Journal of Economics" 1987, Vol. 102, No. 1.

\section{Theory of Loan Agreement: Overview of Studies}

The article reviews theoretical studies on the loan agreement. First, the results of researches in the area of the costly state verification models proving optimality of the standard debt contract in conditions of information asymmetry and 
existence of costs of verification of the debtor's outcomes were analysed. Followed by analysis of the models included in the mainstream of the incomplete contract theory, which assume unpredictability of nature and the need to take into account the role of collateral and the liquidation value on the loan repayment. The focus was also placed on researches taking into account the impact of debt renegotiation and long lender-borrower relationship on the behaviour of the borrower during the repayment of the debt.

Keywords: loan, credit, agreement, contract, theory

\section{La théorie du contrat de crédit - l'aperçu des recherches}

L'article présente un aperçu des recherches théoriques sur le contrat de crédit. Tout d'abord, l'auteur a analysé les résultats des recherches dans le domaine des modèles de "costly state verification". Ensuite, il a analysé les modèles s'inscrivant dans la théorie des contrats incomplets. L'accent a été mis également sur la recherche prenant en compte l'impact de la renégociation de la dette et de la longévité de la relation prêteur-emprunteur sur le comportement de l'emprunteur au cours du remboursement de la dette.

Mots-clés: le crédit, l'accord, le contrat, la théorie

\section{Теория кредитных договоров - обзор исследований}

Статья содержит обзор теоретических исследований по кредитному договору. Во-первых, проанализированы результаты исследований, относящихся к CSV, которые подтверждают оптимальность стандартного кредитного договора в условиях существования информационной асимметрии и расходов, связанных с проверкой должника. Затем анализируются модели, относящееся к теории неполных контрактов, которые предполагают непредсказуемость природы и необходимость учета роли залога и его ликвидационной стоимости в погашении кредита. Внимание было также уделено исследованиям, относящимся к влиянию пересмотра долга и долгосрочных связей кредитор-заемщик на поведение заемщика при погашении задолженности.

Ключевые слова: кредит, контракт, теория, модель 
